\title{
PERILAKU PEMILIHAN MAKANAN DAN DIET BEBAS GLUTEN BEBAS KASEIN PADA ANAK AUTIS
}

\author{
Sri Ramadayanti, Ani Margawati*) \\ Program Studi Ilmu Gizi Fakultas Kedokteran Universitas Diponegoro \\ Jl.Dr.Sutomo No.14, Semarang, Telp (024) 8453708, Email : gizifk@undip.ac.id
}

\begin{abstract}
Background: Feeding and preferencing meal are correctly way to decrease symptom of autism. One of the diet therapies for autism is a GCFC diet. Preferencing meal which is appropriate with current diet must be given correctly to prevent under-nutrition in autism children.

Objective: To analyze food preference behaviour factor and compliance of GCFC diet in autism children.

Method: This study belonged to observasional with cross sectional design using qualitative method. Sampling technique used purposive sampling which was appropriate with inclusion and exclusion criteria. Informants in this study were mother or foster mother of selected autism children as subjects. Data collection used deep interview and observation. FGD (Focus Gruop Discussion) was also used to complete obtained data.

Result: There was no informant practicing GCFC diet consistently. Every mother wanted to their children to get different diet, although they were in same condition. There were internal and external factors influencing practice of GCFC diet in autism children.

Conclusion: Practicing GCFC diet inconsistently is influenced by family and environment support factors. Many snacks containing gluten or casein in house or school area also encourage autism to consume source of gluten and casein.
\end{abstract}

Keywords: food preference; GFCF diet; autism

\begin{abstract}
ABSTRAK
Latar Belakang : Pemberian dan pemilihan makanan secara benar merupakan suatu cara meringankan gejala autisme. Salah satu terapi diet yang dianjurkan pada autisme adalah diet bebas gluten dan bebas kasein. Pemilihan makanan yang sesuai dengan diet yang sesuai pula harus diberikan secara tepat untuk mencegah terjadinya kekurangan gizi pada anak autis.

Tujuan: Menganalisis faktor perilaku pemilihan makanan dan kepatuhan diet bebas gluten bebas kasein pada anak autis.

Metode: Penelitian ini termasuk penelitian observasional dengan desain cross sectional yang menggunakan metode kualitatif. Teknik pengambilan informan secara purposive sampling sesuai kriteria inklusi dan eksklusi. Informan dalam penelitian ini adalah ibu maupun orang tua wali dari anak autis yang terpilih menjadi subjek penelitian. Pengumpulan data dilakukan dengan wawancara mendalam dan observasi. Selain itu juga dilakukan FGD (Focus Group Discusion) yang bertujuan untuk saling melengkapi data yang diperoleh.

Hasil: Tidak terdapat informan yang menerapkan diet bebas gluten bebas kasein secara konsisten. Kesediaan setiap orang tua untuk menginginkan anaknya menjalankan diet berbeda, walaupun anak dalam kondisi sama. Terdapat faktor internal dan eksternal yang mempengaruhi penerapan diet bebas gluten bebas kasein pada anak autis.

Kesimpulan: Penerapan diet bebas gluten bebas kasein yang dilakukan secara tidak konsisten dipengaruhi oleh faktor dukungan keluarga dan lingkungan sekitar. Banyaknya jajanan, baik di lingkungan rumah maupun sekolah yang mengandung gluten maupun kasein juga mendorong anak autis untuk mengkonsumsi makanan sumber gluten dan kasein.
\end{abstract}

Kata Kunci : pemilihan makanan; bebas gluten bebas kasein; autis

\section{PENDAHULUAN}

Autisme

merupakan

gangguan

perkembangan fungsi otak yang berpengaruh pada interaksi sosial dan keahlian berkomunikasi. Kesulitan dalam melakukan komunikasi verbal dan nonverbal, interaksi sosial serta beberapa aktivitas ditunjukkan pada beberapa anak dengan autisme. ${ }^{1}$ Dewasa ini terjadi peningkatan jumlah penyandang autisme di dunia pada beberapa tahun terakhir. ${ }^{2}$ Menurut hasil penelitian yang dilakukan Centers for Disease Control and Prevention pada tahun 2008 terdapat 1 anak autis per 88 anak. Terjadi peningkatan sebesar $23 \%$ selama dua tahun terakhir (2006-2008) dan 78\% selama 6 tahun terakhir (2002-2008). Penelitian tersebut menyatakan peningkatan autisme paling banyak

${ }^{*}$ Penulis Penanggungjawab 
terjadi pada anak-anak Hispanik dan AfrikaAmerika. ${ }^{3}$ Sedangkan angka pasti jumlah autisme di Indonesia belum dapat diketahui secara pasti karena belum terdapat penelitian secara mendalam. ${ }^{4}$

Makanan merupakan suatu hal yang juga harus diperhatikan pada anak dengan gangguan autis. Pemberian serta pemilihan makanan secara benar merupakan suatu cara meringankan gejala autisme. $^{2}$ Salah satu terapi diet yang dianjurkan pada autisme adalah diet bebas gluten dan bebas kasein. Gluten dan kasein pada anak autis tidak diperbolehkan karena terjadi peningkatan permeabilitas usus (leaky gut), sehingga memungkinkan peptide dari kasein dan gluten yang tidak tercerna keluar dari dinding usus masuk ke aliran darah. Selain itu, adanya gangguan enzim Dipeptidylpeptidase IV mengakibatkan gluten dan kasein tidak tercerna dengan sempurna. ${ }^{5}$

Konsumsi gluten dan kasein sebenarnya masih terbilang kurang dilihat dari diet tradisional Indonesia jarang menggunakan gluten dan kasein tersebut, kecuali diet tradisional yang telah terkena pengaruh dari luar. Selain itu sangat penting bagi seseorang yang menerapkan diet bebas gluten bebas kasein untuk membaca label makanan, mengingat banyaknya makanan kemasan menggunakan bahan makanan yang mengandung gluten dan kasein. ${ }^{6}$ Banyak penelitian menyatakan bahwa pemberian makanan rendah gluten dan rendah kasein pada autisme akan memberikan respon terhadap perubahan perilaku. Namun, berat ringannya gangguan perilaku pada anak autis juga dipengaruhi ada tidaknya terapi perilaku, terapi obat dan diet bebas gluten bebas kasein sebelumnya. ${ }^{6,7}$

Peran ibu didalam keluarga selain mengasuh anak juga memegang peranan penting dalam pendampingan proses perkembangan anak termasuk dalam hal pemilihan makanan yang tepat sesuai kebutuhan anak. ${ }^{8}$ Pemilihan makan yang sesuai dengan diet yang sesuai pula harus diberikan secara tepat untuk mencegah terjadinya kekurangan gizi pada anak autis. Selain itu, orang tua anak autis sering melaporkan bahwa masalah makan dapat mempengaruhi pertumbuhan anak mereka. ${ }^{9}$ Oleh karena itu, dengan pemberian diet secara tepat diharapkan anak dengan gangguan autis mendapatkan gizi yang cukup sesuai dengan kebutuhannya sehingga dapat mengikuti terapi dan pendidikan dengan baik. ${ }^{10}$

Penelitian yang telah dilakukan di Semarang membuktikan bahwa sebagian besar anak autis tidak melaksanakan diet bebas gluten dan bebas kasein. Berdasarkan uraian tersebut, perlu dilakukan penelusuran secara mendalam untuk memperoleh informasi mengenai faktor yang melatarbelakangi perilaku pemilihan makanan dan diet bebas gluten bebas kasein pada anak autis. SLB Negeri Semarang merupakan satu-satunya sekolah negeri bagi penyandang autis yang berada di Semarang. Berdasarkan hal tersebut diatas peneliti tertarik untuk melakukan penelitian secara kulaitatif dengan tujuan untuk mengetahui faktor yang melatarbelakangi perilaku pemilihan makanan dan diet bebas gluten bebas kasein pada anak autis di SLB Negeri Semarang.

\section{METODA}

Penelitian ini dilaksanakan di SLB Negeri Semarang pada bulan Juli- Agustus 2012. Penelitian ini termasuk dalam ruang lingkup gizi masyarakat dan merupakan penelitian observasional dengan desain cross sectional yang menggunakan pendekatan kualitatif. Metode kualitatif dipilih karena faktor perilaku pemilihan makan yang melatarbelakangi gambaran diet pada anak autis, diharapkan dapat diungkap lebih mendalam dan mendapatkan temuan baru karena pertanyaan yang diajukan bersifat lebih eksploratif.

Populasi terjangkau adalah anak autis yang bersekolah di SLB Negeri Semarang masuk dalam kelas $\mathrm{C}, \mathrm{C} 1$ dan pengembangan. Informan dalam penelitian ini adalah ibu maupun orang tua wali dari anak autis yang terpilih menjadi subjek penelitian. Pengambilan informan dilakukan dengan metode purposive sampling sesuai dengan kriteria inklusi dan eksklusi. ${ }^{12-14}$ Proses perekrutan subjek dilakukan dengan mengumpulkan data anak autis yang termasuk dalam kelas $\mathrm{C}, \mathrm{C} 1$ dan pengembangan dilihat dari data sekunder yang didapatkan dari pihak sekolah. Kriteria inklusi informan adalah ibu maupun orang tua wali yang memiliki anak autis di kelas $\mathrm{C}, \mathrm{C} 1$ atau pengembangan, dapat berkomunikasi dengan baik, dan bersedia menjadi informan penelitian dengan mengisi informed consent. Sedangkan kriteria eksklusinya adalah informan meninggal dunia pada saat proses penelitian, subjek pindah sekolah dan informan memutuskan untuk berhenti menjadi partisipan pada saat proses penelitian.

Berdasarkan teknik sampling diatas, didapatkan 16 orang yang bersedia menjadi informan tetapi satu diantaranya drop out karena informan menolak diwawancarai pada pertemuan berikutnya, sehingga total informan penelitian adalah 15 informan. Pengumpulan data dilakukan dengan metode wawancara mendalam (in depth 
interview) yang dilanjutkan dengan observasi atau pengamatan. ${ }^{11,12}$ Selain itu juga dilakukan FGD (Focus Group Discusion) pada 12 informan yang telah bersedia melakukan diskusi secara kelompok, FGD dilakukan di ruangan yang telah disediakan oleh pihak sekolah. Observasi dilakukan terhadap kebiasaan pemilihan makan anak autis dan proses terapi diet bebas gluten bebas kasein yang sedang dilaksanakan.

Jenis data yang dikumpulkan meliputi gambaran kepatuhan diet bebas gluten bebas kasein, dilihat dari konsumsi makanan yang mengandung gluten dan kasein diperoleh dengan menggunakan food frequency semi qualitative (FFSQ) selama tiga bulan terakhir. Selain itu juga digunakan food recall 24 jam selama 3 hari tidak berurutan untuk memperoleh gambaran kebiasaan makan anak autis dan asupan gizinya. Faktorfaktor yang melatarbelakangi perilaku pemilihan makan pada anak autis bisa diketahui dari wawancara dan FGD terhadap informan.

Pengujian keabsahan data kualitatif dilakukan dengan memenuhi empat kriteria yaitu kepercayaan (credibility), keteralihan (transferability), kebergantungan (dependability) dan kepastian (confirmability). ${ }^{11,12}$ Credibility hasil penelitian dicapai dengan melakukan triangulasi kepada informan. Pengujian dilakukan dengan membandingkan hasil wawancara mendalam informan dengan keterangan dari orang sekitar informan. Wawancara dilakukan dengan informan terlebih dahulu lalu dilanjutkan dengan orang disekitar informan dengan atau tanpa informan.
Pada saat wawancara dilakukan usaha untuk mencegah intervensi jawaban yang dapat mempengaruhi informan. ${ }^{11}$

Transferability dicapai dengan menguraikan penelitian secara rinci. Dependability dicapai dengan cara melakukan auditing (pemeriksaan) dengan seseorang yang berkompeten di bidangnya. Peneliti melakukan auditing dengan pembimbing penelitian. Confirmability dilakukan pada saat wawancara terakhir dengan informan untuk mendapatkan kepastian dan objektivitas data yang telah diperoleh. ${ }^{12}$ Analisis dilakukan bersamaan dengan proses pengumpulan data dengan model analisis isi (content analisys). ${ }^{13}$ Proses analisis data dimulai dengan mengumpulkan seluruh data hasil wawancara, observasi, catatan lapangan dan diskusi kelompok. Selanjutnya dilakukan koding data dengan menemukan pola berdasarkan hasil wawancara, observasi untuk mengkategorikan data, merumuskan tema dan mencari kaitan antar tema dan kategori berdasarkan tinjauan literatur, merumuskan hipotesis kerja yang dapat menjawab pertanyaan penelitian dan mengintegrasikan hasil analisis dalam bentuk deskriptif. ${ }^{13}$

\section{HASIL DAN PEMBAHASAN Karakteristik Subjek}

Subjek penelitian ini adalah 15 anak dengan usia berkisar 6-14 tahun yaitu dari kelas satu hingga delapan. Berikut karakteristik subjek penelitian yang terdiri dari jenis kelamin, usia saat diagnosis dan usia saat penelitian.

Tabel 1. Karakteristik subjek penelitian menurut jenis kelamin, usia saat diagnosis dan usia saat penelitian

\begin{tabular}{lllcc}
\hline No. & \multirow{2}{*}{ Karakteristik } & & \multicolumn{2}{c}{ Frekuensi } \\
\cline { 3 - 5 } & & $\mathrm{n}$ & $\%$ \\
\hline 1. & Jenis kelamin & Laki-laki & 12 & 80 \\
& & Perempuan & 3 & 20 \\
& & Jumlah & $\mathbf{1 5}$ & $\mathbf{1 0 0}$ \\
\hline 3. & Usia saat diagnosis & $\leq 3$ tahun & 10 & 66,7 \\
& & $>3$ tahun & 5 & 33,3 \\
& & Jumlah & $\mathbf{1 5}$ & $\mathbf{1 0 0}$ \\
\hline 2. & Usia saat penelitian & $6-11$ tahun & 9 & 60 \\
& & $\geq 12$ tahun & 6 & 40 \\
& & Jumlah & $\mathbf{1 5}$ & $\mathbf{1 0 0}$ \\
\hline
\end{tabular}

Hasil penelitian menunjukkan bahwa jumlah anak autis sebagian besar laki-laki yaitu 80\%. Penelitian dari Autism Research Centre of Cambridge University menyatakan adanya 1 kasus anak autis per 175 bayi atau 58 per 10.000 kelahiran dengan perbandingan laki-laki dan perempuan diperkirakan 3:1. ${ }^{14}$ Penelitian di Jakarta didapatkan hasil jumlah anak laki-laki autis dapat mencapai tiga sampai empat kali lebih besar daripada anak perempuan. ${ }^{4}$ Perbandingan antara 
anak autis laki-laki dan perempuan pada penelitian ini adalah 4:1. Hal tersebut serupa dengan penelitian menurut Hartono yang menyatakan perbandingan anak autis laki-laki dan perempuan sebesar $4: 1 .^{2}$

Data penelitian menurut usia anak saat terdiagnosis autis pertama kali, menyebutkan dari lima belas subjek yang diteliti diketahui bahwa anak terdiagnosis autis antara sejak lahir sampai berusia delapan tahun. Sebagian besar anak terdiagnosis autis untuk pertama kalinya pada usia
1 dan 2 tahun, yaitu masing-masing berjumlah 3 anak. Gangguan autis atau Autism Spectrum Disorders biasanya terlihat jelas sebelum berumur tiga tahun. ${ }^{3}$ Penelitian di Amerika Serikat yang dilakukan dengan metode retrospektif, menyebutkan rata-rata usia anak mengalami gangguan autis berkisar 10 bulan sampai 2,7 tahun. Hal tersebut diketahui dari pengamatan orang tua ketika pertama kali melihat karakteristik gejala autis pada anak mereka. ${ }^{15}$

Tabel 2. Karakteristik orang tua

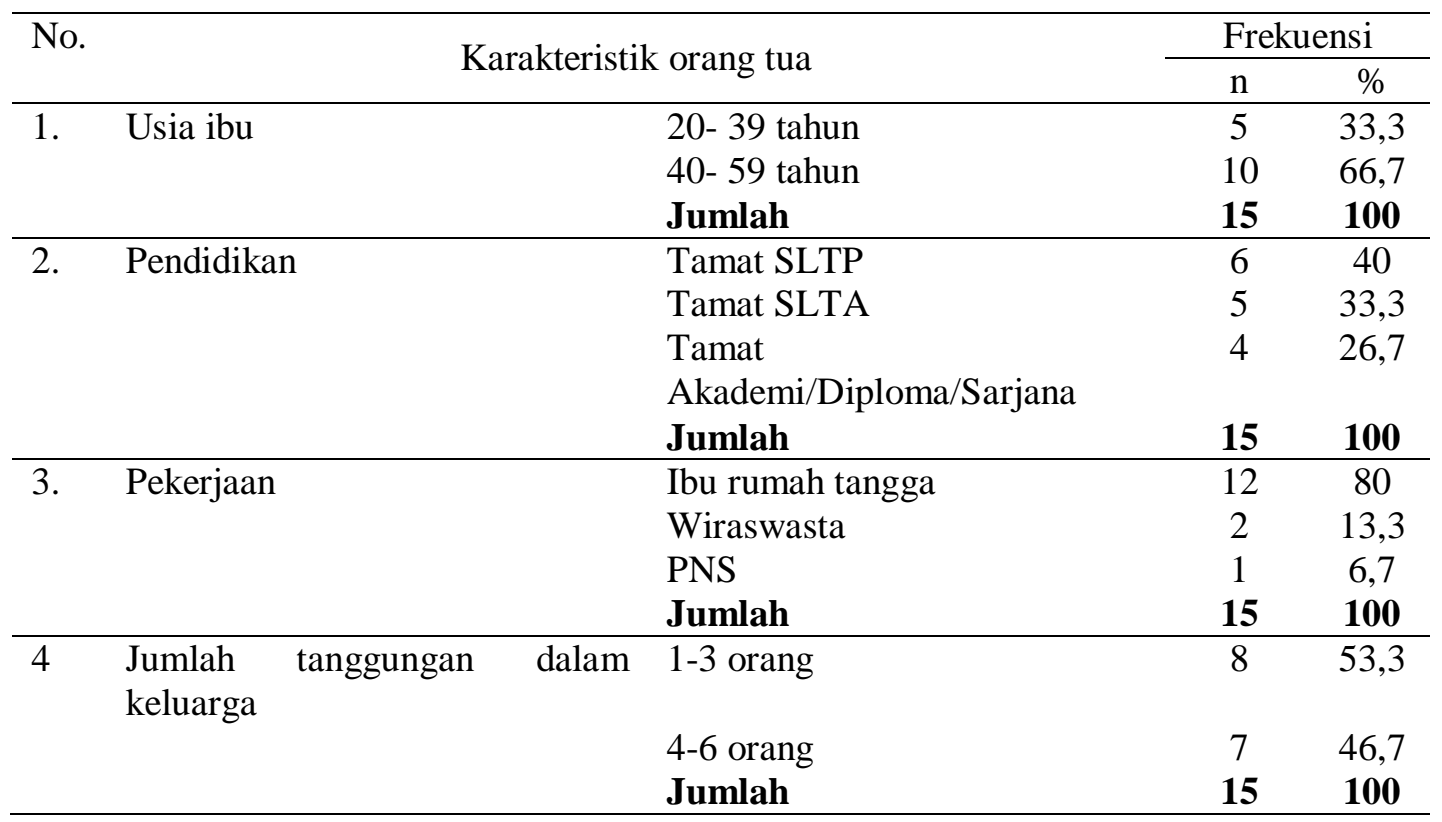

Tabel 2 menunjukkan karakteristik orang tua berdasarkan usia ibu, pendidikan ibu, pekerjaan ibu dan jumlah tanggungan dalam keluarga. Berdasarkan tabel tesebut, diketahui lebih dari separuh orang tua subjek $(66,7 \%)$ berusia $40-59$ tahun yang secara keseluruhan merupakan ibu subjek. Pendidikan terakhir ibu subjek yang paling banyak adalah tamat SLTP (40\%). Pekerjaan ibu yang paling banyak adalah ibu rumah tangga yaitu sebanyak $80 \%$. Persentase tanggungan dalam satu keluarga yang berjumlah 1-3 orang termasuk ibu subjek adalah $53,3 \%$ dan sisanya $46,7 \%$ yang mempunyai jumlah tanggungan keluarga sebanyak 4-6 orang. Semakin tinggi tingkat pendidikan formal orang tua maka semakin tinggi kemampuan mereka untuk menyerap informasi, dengan demikian pengetahuan dan wawasannya tentang autis akan lebih luas sehingga dalam penanganannya juga lebih baik. ${ }^{16}$

Perilaku Pemilihan Makanan Pada Anak Autis
Pemilihan jenis makanan yang benar secara tidak langsung akan mempengaruhi status gizi anak. Permasalahan makan pada anak autis diantaranya yaitu menolak makan, picky eaters (memilih-milih makanan), kesulitan menerima makanan baru, tantrum dan gerakan mengunyah sangat pelan. ${ }^{17}$ Sebagian besar anak autis mempunyai pola makan idiosyncratic dan perilaku makan yang tidak biasa. Hal tersebut dapat berupa sedikitnya variasi diet, keengganan pada tekstur makanan tertentu atau sangat suka pada makanan tertentu. ${ }^{18}$

"...Anak saya makannya monoton, sukanya ayam goreng, tahu terus tempe, nggak doyan yang rasa-rasa keju apalagi kejunya. Suka susu rasa cokelat, roti isi cokelat tidak terlalu sering, wafer suka yang rasa cokelat..." (I.2, ibu, 46 tahun)

“...Anak saya sukanya makan rempeyek, tempe keripik, roti maunya yang roti 
kering, roti basah tidak mau..." (I.9, ibu, 42 tahun)

“...Cemilan yang disukai ya roti kering, biskuit-biskuit, roti basah anak nggak suka..." (I.10, ibu, 49 tahun)

Pengetahuan informan yang sebagian besar merupakan ibu dalam kehidupan sehari-hari sangat dibutuhkan bagi anak autis, dalam hal ini pengetahuan tentang penyelenggaraan makanan keluarga sehingga diharapkan ibu dapat menyusun pola makan yang baik bagi anak autis.

“...Menu sehari-hari ya ada nasi, sayur capcay sama orak-arik, suka semua. Kata ibu $x$ (seorang terapis) telur sama ikan laut nggak boleh. Yang boleh lele, ikan air tawar, belut. Sayur gambas dibolehin. Madu nggak boleh. Buah jeruk nggak boleh, pisang nggak mau. Buah sukanya yang berair, yang disukai mangga..." (I.5, ibu, 40 tahun)

\section{“...Sumber karbohidratnya nasi, proteinnya lauk pauk seperti ayam, telur,dan tempe. Sayur, anak masih kuahnya saja. Buah sedang dijalankan untuk diberikan kepada anak, soalnya anak tidak suka..." (I.7, ibu, 38 tahun)}

Pemilihan makan yang sesuai dengan diet yang sesuai pula harus diberikan secara tepat untuk mencegah terjadinya kekurangan gizi pada anak autis. Hal tersebut sering dilaporkan oleh orang tua anak autis. Hasil penelitian di Yogyakarta menyebutkan bahwa terdapat permasalahan makan yang dapat mempengaruhi pertumbuhan anak. ${ }^{9}$ Sebanyak 2 informan (13,3\%) sengaja tidak memberikan maupun menerapkan diet apapun kepada anak mereka dengan alasan bahwa diet maupun bentuk pelarangan jenis-jenis makanan tertentu dapat menghambat kebutuhan gizi anak mereka.

\footnotetext{
“...Diet sudah pernah, tetapi ibu akhirnya berpikir kalo diet itu tidak baik bagi anak autis, jadi dietnya cuma nggak makan cokelat, mie instant sekali-sekali saja. Kasihan anak kalo disuruh diet dilarang makan ini itu, nanti kurang nutrisi..." (I.1, nenek, 52 tahun)

“...kami tidak ingin menghambat pasokan gizi pada anak. selain itu berat badan anak sudah ideal, tidak ada permasalahan makan anak..."(I.15, ibu, 49 tahun)
}

Gambaran asupan serat subjek penelitian dapat dilihat berdasarkan hasil recall 24 jam selama 3 hari secara tidak berurutan. Berdasarkan hasil perhitungan terdapat sebanyak 7 subjek $(46,67 \%)$ memiliki asupan serat dalam kategori kurang, 6 subjek (40\%) dalam kategori lebih dan 2 subjek (13,33\%) dalam kategori normal. Berdasarkan Widyakarya 2004, RDA (Recommended Dietary Allowances) serat untuk anak adalah 10-14 gram/ 1000 kkal. ${ }^{19}$ Penelitian di Amerika Serikat menyatakan adanya kekurangan serat pada seseorang yang melakukan diet bebas gluten. ${ }^{20}$ Hasil penelitian menunjukkan orang tua anak sudah berusaha untuk memberikan yang terbaik untuk anaknya melalui penyelenggaraan makan untuk anak dengan pemilihan makan yang sesuai kebutuhan. Hal tersebut diharapkan pemilihan makan secara tepat sesuai kebutuhan anak dapat mencegah terjadinya kekurangan gizi pada anak autis. Namun, permasalahan dapat dilihat dari berbagai jenis makanan jajanan yang sering dikonsumsi anak sehingga anak cenderung lebih menyukai jajanan dibandingkan makanan utama. Pengenalan makanan jajanan pada anak autis juga berpengaruh terhadap konsumsi makanan sehari-hari, sebab anak autis cenderung menjadi lebih sulit untuk mematuhi diet yang dianjurkan karena biasanya mereka susah makan dan hanya menginginkan makan makanan tertentu yang justru tidak baik untuk mereka.

Anak-anak autis pada umumnya tumbuh pada tingkat yang khas pada kelompok usia mereka dengan pola makan sebanding dengan asupan pada anak-anak berkembang pada umumnya. Banyak laporan kasus yang menunjukkan adanya permasalahn pada pemberian makanan, terutama adanya penolakan makan (food refusal) dan selektifitas atau memilih-milih makanan. Modifikasi perilaku sebaiknya sudah diterapkan sejak dini yang diperluas hingga makanan dengan targetnya berupa perilaku yang bertujuan untuk meningkatkan penerimaan bagi anak autis dan tentunya dengan pemberian diet yang bervariasi. ${ }^{1}$

\section{Diet Bebas Gluten Bebas Kasein Pada Anak Autis}

Makanan anak autis pada umumnya sama dengan makanan untuk anak normal lainnya, yaitu harus memenuhi gizi seimbang dan tetap harus memperhatikan aspek pemilihan makanan. Diet yang umumnya diterapkan pada anak autis adalah diet bebas gluten dan bebas kasein. Tujuan dari 
intervensi diet pada anak autis adalah untuk menghilangkan gejala autis, menghentikan atau menunda proses degeneratif yang berlangsung, meningkatkan kualitas hidup, serta memberikan status gizi yang baik bagi penyandang autis. ${ }^{2}$

Berdasarkan hasil wawancara sebanyak 7 informan $(46,7 \%)$ tidak mengetahui istilah dari diet bebas gluten bebas kasein (Gluten Free Casein Free) dan sebanyak 8 informan (53,3\%) mengetahui pengertian diet bebas gluten bebas kasein. Terdapat 6 informan $(40 \%)$ belum pernah menerapkan diet bebas gluten bebas kasein pada anak mereka, sedangkan sebanyak 7 informan $(46,7 \%)$ sudah menerapkan diet tersebut yaitu baik yang masih berlangsung sampai sekarang maupun tidak. Tidak satu pun informan yang sudah menerapkan diet bebas gluten bebas kasein secara konsisten, hal tersebut diketahui dari jenis makanan yang dikonsumsi selama tiga bulan terakhir dilihat dari hasil wawancara dan pengisian formulir FFSQ.

“...Dulu belum pernah diet gluten kasein, menerapkan diet setelah mengetahui anak ada alergi. Umur 2 tahun tepatnya bulan Desember tahun 2000, anak merah-merah disekitar mulut. Kemudian berhenti minum susu sapi, sampai usia 2,5 tahun diamati merah-merah dimulut hilang. Sekarang bebas, nggak dilarang-larang. Anak paling suka ayam goreng tepung..." (I.11, ibu, 49 tahun)

“...diet bebas gluten bebas kasein tidak mengkonsumsi makanan dari tepung terigu atau gandum dan makanan atau minuman yang mengandung susu beserta turunannya. Sudah menerapkan pada anak selama 5 bulan tetapi belum konsisten..." (I.7, ibu, 38 tahun)

“...sering disarankan diet bebas gluten kasein, belum pernah dengar arti sebenarnya, ya yang dilarang susu, buahbuahan yang dimakan semangka sama pepaya, nggak boleh cokleat terus chickichicki. Yang boleh dari tepung beras, susu kedelai. Selalu menerapkan, cuma anaknya nggak mau, jadi sampai sekarang makan pada umumnya..." (I.3, ibu, 29 tahun)

Penghapusan gluten dan/ atau kasein pada anak autis, selama bertahun-tahun dilaporkan oleh banyak orang tua terkait dengan diet bebas gluten bebas kasein memberikan perbaikan yang signifikan dalam perilaku. ${ }^{21}$ Efek yang dirasakan dan berdasarkan pengamatan orang tua anak-anak autis yang pernah menjalankan diet ataupun yang masih berlangsung hingga saat ini berbeda-beda. Lebih dari separuh informan $(66,7 \%)$ mengatakan terdapat perubahan salah satunya perilaku anak mereka pada saat anak menjalankan diet bebas gluten bebas kasein secara benar. Sebanyak 5 informan $(33,3 \%)$ mengatakan belum tahu apakah diet bebas gluten bebas kasein memberikan manfaat baik dari segi perubahan perilaku ataupun tidak ada perubahan sama sekali, sehingga mereka memilih untuk menghentikan diet maupun sengaja tidak menjalankan diet.

“...manfaat yang diamati, anak emosinya menjadi lebih berkurang. Kalau sekarang nggak ngaruh dikasih diet suruh menghindari gandum-ganduman..." (I.4, ibu, 41 tahun)

“...kalau kebanyakan makan tepung gandum, mendoan, bakso nanti anak jadi error. Tapi menguranginya sedikit demi sedikit..." (I.6, ibu, 48 tahun)

Sangat sulit menghindari makanan barat yang sangat populer dikalangan anak-anak seperti fried chicken, hamburger dan pizza yang sebagian besar terdapat kandungan gluten. Selain itu, ice cream yang sangat digemari anak-anak perlu dihindari karena ice cream terbuat dari susu, demikian juga milk chocolate. ${ }^{6}$ Keterbatasan akan sedikitnya variasi makanan yang tidak mengandung gluten dan kasein menjadi salah satu masalah yang harus dihadapi orang tua anak autis dalam menjalankan diet bebas gluten bebas kasein. “...sebenarnya nggak ada kesulitan dalam menjalankan diet. Hanya nggak tega pada anak, soalnya anak menderita epilepsi juga jadi harus diberi banyak makanan bergizi, seperti susu sapi bubuk tetap diberikan..." (I.12, pengasuh, 30 tahun)

“...anak susah makan, makan ayam goreng saja harus dipotong kecil-kecil dan harus kriuk-kriuk baru anak nafsu makan. Jajan diluar seperti ice cream, kalau minta ice cream sering dialihkan, tapi ketika menangis kasian juga pada anak akhirnya dibelikan..." (I.14, ibu, 29 tahun)

“...mencari makanan untuk anak autis cukup sulit ya, apalagi makanan dari luar banyak yang tidak diperbolehkan. Jadi 
harus masak sendiri, sedikit merepotkan. Tapi kebetulan anak nggak suka ngemil..." (I.2, ibu, 46 tahun)

“...pelaksanaan diet anak autis harus semaksimal mungkin, harus ganti menu tiap hari tetapi menu anak autis sedikit, orang rumah tidak bisa mengikuti menu yang monoton. Perilaku anak dipengaruhi 90\% dari makanan yang dimakan, tetapi susah dalam pelaksanaannya. Apalagi punya adik yang usianya 8 tahun, adiknya makan apa saja kakanya juga ikut makan, begitu juga sebaliknya..." (I.5, ibu, 40 tahun)

Penerapan diet bebas gluten bebas kasein dipengaruhi oleh faktor internal dan eksternal. Faktor internal berasal dari dalam diri anak autis maupun ibu itu sendiri, sedangkan faktor eksternal yang akan mendukung penerapan diet secara konsisten berasal dari lingkungan sekitar termasuk orang-orang di sekitarnya. Peran ibu sangat dibutuhkan dalam pengawasan pada pola makan anak, hal tersebut dikarenakan ibu sebagai orang terdekat sekaligus penyelenggara makan pada anak. Komitmen sangat dibutuhkan dalam menjalankan diet bebas gluten bebas kasein pada anak karena diet harus dilakukan dirumah, sekolah dan dimanapun saat anak makan. Selain itu, terdapat faktor yang dapat mempengaruhi perilaku orang tua dalam menerapkan diet bebas gluten bebas kasein pada anak yaitu perilaku anak autis itu sendiri yang memungkinkan menjadi pengahambat jalannya pelaksanaan diet.

Keberhasilan penerapan diet bebas gluten bebas kasein pada anak autis sangat dipengaruhi oleh lingkungan. Keterlibatan orang-orang dirumah pada pelaksanaan diet tersebut akan memberi pengaruh kepada seluruh anggota keluarga dirumah yang secara tidak langsung membutuhkan penyesuaian dalam penerapan diet yang sedang dijalankan. ${ }^{22}$ Selain itu, faktor eksternal lainnya adalah adanya ketersediaan pangan sumber gluten dan kasein yang masih banyak ditemui di pasaran maupun di lingkungan sekitar. Berdasarkan penelitian, makanan sumber gluten dan kasein beserta macam-macam olahannya masih banyak dikonsumsi oleh anak autis, dimana beberapa jenis diantaranya termasuk makanan yang disukai mereka. Anak- anak autis tersebut masih tergolong mudah dalam mengakses makanan-makanan yang mengandung gluten maupun kasein yaitu baik yang tersedia di minimarket, kantin sekolah maupun toko makanan di lingkungan rumah.

Hambatan dalam menerapkan diet bebas gluten bebas kasein dapat terjadi adanya perilaku anak autis seperti perilaku tantrum dan picky eaters yang muncul pada anak sehingga membuat orang tua mengalah karena tidak tega. Ketidakberdayaan orang tua dalam menangani perilaku anak autis yang memiliki banyak permasalahan makan, serta ketersediaan makanan di lingkungan sekitar yang tidak memungkinkan secara tidak langsung dapat mempengaruhi perilaku orang tua dalam penerapan diet bebas gluten bebas kasein secara konsisten.

Gambaran konsumsi berbagai bahan makanan sumber gluten dan kasein beserta olahannya yang paling banyak dikonsumsi anak autis, dapat dilihat berdasarkan frekuensi maksimum bahan makanan yang mengandung gluten dan kasein pada tabel 4.

Tabel 4. Frekuensi konsumsi bahan makanan yang mengandung gluten dan kasein

\begin{tabular}{|c|c|c|c|}
\hline \multirow{3}{*}{ No. } & \multirow{3}{*}{ Bahan makanan } & \multicolumn{2}{|c|}{ Frekuensi } \\
\hline & & Jumlah konsumen & Rerata konsumsi \\
\hline & & $\mathrm{n}$ & $\mathrm{x} /$ minggu \\
\hline \multirow[t]{2}{*}{1.} & Sumber gluten: & & \\
\hline & Tepung terigu & 15 & 1,11 \\
\hline \multirow[t]{3}{*}{2.} & Hasil olah gluten : & & \\
\hline & - Biskuit dari tepung terigu & 13 & 0,75 \\
\hline & - Wafer & 13 & 0,90 \\
\hline \multirow[t]{2}{*}{3.} & Sumber kasein & & \\
\hline & Susu sapi & 5 & 1,65 \\
\hline \multirow[t]{2}{*}{4.} & Hasil olah kasein : & & \\
\hline & Susu fermentasi & 5 & 0,76 \\
\hline 5. & $\begin{array}{l}\text { Kasein terselubung: } \\
\text { Ice cream }\end{array}$ & 9 & 0,52 \\
\hline
\end{tabular}


Berdasarkan tabel diatas menunjukkan bahwa semua subjek masih mengkonsumsi sumber gluten yang berupa tepung terigu yaitu dengan rerata konsumsi 1,11 x/ minggu. Hasil olahan gluten yang paling sering dikonsumsi oleh anak autis berupa wafer dan biskuit dengan bahan dasar tepung terigu. Sebanyak 5 subjek pada penelitian ini masih mengkonsumsi sumber makanan yang mengandung kasein dan olahannya yaitu berupa susu sapi dan susu fermentasi dengan rerata konsumsi masing-masing 1,65 dan 0,76 x/ minggu. Sedangkan ice cream yang banyak digemari anakanak, mengandung kasein terselubung dikonsumsi sebanyak 9 anak autis dengan rerata konsumsi 0,52 $\mathrm{x} /$ minggu. Hasil dari penelitian yang ditunjukkan oleh instrumen FFSQ dapat diketahui bahwa masih banyaknya anak autis yang belum dapat melaksanakan diet bebas gluten bebas kasein. Hal tersebut tidak bisa dipungkiri karena masih banyaknya produk makanan yang mengandung gluten maupun kasein. Selain itu juga terbatasnya jenis makanan yang tidak mengandung gluten dan kasein yang diketahui ibu untuk disajikan kepada anak mereka. ${ }^{23}$

Hasil FGD menunjukkan bahwa sumber informasi terbanyak yang diperoleh informan mengenai diet bebas gluten bebas kasein berasal dari dokter yang pernah menangani anak mereka. Separuh dari informan yang mengikuti diskusi menyatakan bahwa sudah menerapkan diet bebas gluten bebas kasein pada anak mereka, tetapi pelaksanaannya belum konsisiten. Faktor yang melatarbelakangi pelaksanaan diet yang tidak konsisten tersebut diketahui bahwa orang tua merasa mempunyai kesulitan dalam menjalankan diet tersebut, salah satu diantaranya dikarenakan masih banyaknya makanan jajanan baik di supermarket maupun di lingkungan sekolah yang menyediakan makanan yang banyak mengandung gluten dan/ atau kasein. Hal tersebut merupakan salah satu contoh bahwa faktor lingkungan juga berpengaruh terhadap pelaksanaan diet bagi anak autis. Faktor lainnya diketahui kurangnya dukungan dari berbagai pihak yaitu dari ibu sendiri sebagai penyelenggara makan dalam keluarga, anggota keluarga, maupun pihak sekolah tempat anak bersekolah.

Salah satu informan menyatakan bahwa kerjasama dengan keluarga dan lingkungan sekitar sangat penting untuk mendukung berjalannya diet anak autis, dimana makanan khusus anak autis masih tergolong jarang dan susah untuk didapatkan. Selain itu penting adanya motivasi dalam diri ibu maupun keluarga anak autis untuk menjalankan diet, dengan harapan penerapan diet yang dijalankan tetap memberikan asupan gizi yang sesuai dan membawa perubahan perilaku anak menjadi lebih baik. Penyebab autis yang multifaktoral menyebabkan setiap individu mempunyai permasalahan yang berbeda-beda, hal tersebut juga yang melatarbelakangi ketidakpatuhan anak terhadap diet bebas gluten bebas kasein. Kesediaan setiap orang tua untuk menginginkan anaknya menjalankan diet berbeda, walaupun dalam kondisi sama sehingga diperlukan penyuluhan keluarga untuk mengatasi perbedaan kesediaan perubahan masing-masing keluarga anak autis.

\section{KETERBATASAN PENELITIAN}

Keterbatasan penelitian ini yaitu penelitian hanya mengambil populasi di SLB Negeri Semarang yang memungkinkan adanya informasi yang tidak didapatkan peneliti secara mendalam. Sehingga perlu dilakukan penelitian lebih lanjut dengan populasi lebih luas dengan variasi pangan yang beraneka ragam di wilayah lain untuk melengkapi data yang telah diperoleh.

\section{SIMPULAN}

Penerapan diet bebas gluten bebas kasein yang dilakukan secara tidak konsisten dipengaruhi oleh faktor dukungan keluarga dan lingkungan sekitar termasuk ketersediaan makanan yang ada. Banyaknya jajanan sebagai salah satu faktor eksternal, baik di lingkungan rumah maupun sekolah yang mengandung gluten maupun kasein juga mendorong anak autis untuk mengkonsumsi makanan sumber gluten dan kasein. Hal tersebut dapat dilihat dari perilaku pemilihan makanan sehari-hari anak autis.

\section{SARAN}

Untuk meningkatkan penerapan diet bebas gluten bebas kasein secara konsisten pada anak autis diperlukan sosialisasi dan konseling dengan sasaran secara perorangan/ individu agar tidak terjadi kesalahan dalam pengaturan diet anak yang dapat menyebabkan kekurangan gizi. Sedangkan sosialisasi dilakukan dengan sasaran orang tua dan keluarga anak autis serta pihak sekolah yang berhubungan langsung dengan anak autis. Selain itu, perlu diperkenalkan cara memodifikasi makanan yang tidak mengandung gluten dan kasein serta macam-macam makanan alternatif sebagai pengganti makanan sumber gluten dan kasein yang masih jarang tersedia di pasaran 
kepada orang tua, keluarga, serta pihak sekolah yang menagani anak autis.

\section{DAFTAR PUSTAKA}

1. Mitchel Mary Kay. Nutrition across the life span. In: Nutrition for children with special needs. 2nd edition . USA: Elsevier-Saunders; 2003.p.322.

2. Sri Achadi Nugraheni. Efektivitas intervensi diet bebas gluten bebas casein terhadap perubahan perilaku anak autis. Semarang: Pustaka Rizki Putra; 2008.

3. Centers for Disease Control and Prevention. Morbidity and Mortality Weekly Report: Prevalence of Autism Spectrum Disorders- Autism and Developmental Disabilities Monitoring Network, 14 Sites, United States, 2008. United States : Office Surveillance, Epidemiology, and Laboratory Services, Centers [homepage on the Internet]. 2012 [dikutip pada tanggal 16 April 2012]. Diunduh dari : http://www.cdc.gov/mmwr/pdf/ss/ss6103.pdf

4. Nurlaila Abdullah Mashabi, Nur Rizka Tajudin. Hubungan antara pengetahuan gizi ibu dengan pola makan anak autis. Makara Kesehatan vol 13 No.2, Desember $2009: 84-86$.

5. Melly Budhiman, Paul Shattock, Endang Ariani. Langkah awal menanggulangi autisme dengan memperbaiki metabolisme tubuh. Jakarta : Nirmala; 2002.p. 10-59.

6. Johanes Chandrawinata. Terapi diet pada autisme. Seminar \& workshop on fragile- $\mathrm{X}$ mental retardation, autism and related disorder. Badan penerbit Universitas Diponegoro. Semarang; 2002.

7. Shattock Paul, Paul Whiteley. Langkah intervensi biomedik untuk penanganan autisme dan sejenisnya (Terjemahan). Seminar: Intervensi biomedis pada gangguan autisme dan sejenisnya. Yayasan Autisme Indonesia. Jakarta; 2001.26-48.

8. Marion Jean Claude. Statistics and epidemiology: The number of cases of autism has grown tenfold in the United Kingdom. L'Express. 2001; 17(1)27.

9. Fitria Nur Rahmi. Hubungan pola konsumsi anak autisme dengan perilaku autisme di SLB khusus autistik Fajar Nugraha dan SLB autisme Dian Amanah Yogyakarta. [Skripsi]. Universitas Gajah Mada. 2005.

10. Maulana Mirza. Anak autis; mendidik anak autis dan gangguan mental lain menuju anak cerdas dan sehat. Jogyakarta: Katahati. 2007.

11. Saryono, Mekar Dwi Anggaraeni. Metodologi penelitian kualitatif dalam bidang kesehatan. Yogyakarta: Nuha Medika; 2010.

12. Lexy J Moleong. Metodologi penelitian kualitatif (edisi revisi). Bandung: Remaja Rosdakarya; 2010.

13. Patton Michael Quinn. Metode evaluasi kualitatif. Yogyakarta: Pustaka Pelajar; 2009.

14. Marion Jean Claude. Statistics and epidemiology: The number of cases of autism has grown tenfold in the United Kingdom. L'Express. 2001; 17(1)27.
15. Robin P. Goin-Kochel, Barbara J. Myers. Parental report of early autistic symptoms: Differences in ages of detection and frequencies of characteristics among three autism-spectrum disorders. Volume II Number 2. USA: Journal on developmental disabilities.

16. Ari Tri Astuti. Hubungan antara pola konsumsi makanan yang mengandung gluten dan kasein dengan perilaku anak autis pada sekolah khusus autis di Yogyakarta [Skripsi]. Universitas Gajah Mada. 2009.

17. Lewinsohn Peter M, Jill M Holm Denoma MS, Jeffrey M Gau, Thomas E Joiner, Ruth StriegelMoore, Patty Bear, et al. Problematic eating and feeding behaviors of 36-months-old children. International Journal of Eating Disorders.2005; 38:3, 208-219.

18. Ahearn William H, Tood Castine, Karen Nault, Gina Green. An assessment of food acceptence in children with autisme or pervasive developmental disorder- not otherwise specified. J Autisme Dev Disord.2001; 31, 505-511.

19. Clara M Kusharto. Serat makanan dan peranannya bagi kesehatan. Jurnal Gizi dan Pangan. November 2006;1(2): 45-54.

20. Thompson, Tricia. Folate, iron, and dietary fiber content of the gluten free diet. J Am Diet Assoc.2000;100(11).p289.

21. Whiteley Paul, Jacqui Rodgers, Dawn Savery, Paul Shattock. A gluten-free diet as an intervention for autism and associated spectrum disorders: Preliminary Findings. SAGE Publications and The National Autistic Society.1999;3(1) 45-65.

22. Gwenda Washnieski. Gluten-free and casein-free diets as a form of alternative treatment for autism spectrum disorders. [Thesis]. University of Wisconsin-Stout. 2009 [dikutip pada tanggal 30 Oktober 2012]. Diunduh dari: http://www.uwstout.edu/content/lib/thesis/2009/20 09washnieskig.pdf

23. Paramita Adi Nurmutia. Perbedaan pengetahuan ibu, konsumsi makan (energi, protein, gluten, dan kasein) dan status gizi pada berbagai kelas autis. [Skripsi]. Universitas Diponegoro. 2011. 